\title{
Factors Affecting Polytechnic Students' Perception of Building-Based Vocational Skills
}

\author{
Peter Oluwatoyin Adewale, Olasunmbo Omobolanle Adhuze* \\ Department of Architectural Technology, School of Environmental Studies Federal Polytechnic, Ado-Ekiti, Nigeria \\ Email address: \\ efformass@yahoo.com (P. O. Adewale), bhephzibar@yahoo.com (O. O. Adhuze) \\ ${ }^{*}$ Corresponding author
}

\section{To cite this article:}

Peter Oluwatoyin Adewale, Olasunmbo Omobolanle Adhuze. Factors Affecting Polytechnic Students' Perception of Building-Based Vocational Skills International Journal of Vocational Education and Training Research. Vol. 3, No. 4, 2017, pp. 29-35. doi: 10.11648/j.ijvetr.20170304.11

Received: February 20, 2017; Accepted: March 10, 2017; Published: October 10, 2017

\begin{abstract}
An attempt to reposition the Nigerian economy has led to the introduction of entrepreneurship education in all the country's tertiary institutions with a view to redirecting the youths to technical and entrepreneurial skills for self-employment. Recent studies, however, show low enrolment of students in building related skills at the vocational centres of these institutions despite the important role the sector plays in the socio economic development of the country. While several efforts have been made to explain the reasons for this sombre scenario, empirical-based evidence on the influence of socio-economic background on the attitudes of students towards the acquisition of these skills is lacking. The aim of this study, which was based on Ajzen's Theory of Planned Behaviour, is to explore the influence of gender and family's occupational background on the attitudes of polytechnic students towards building-based vocational skills. Data were sourced through structured questionnaire administered on 358 randomly selected students from the Federal Polytechnic, Ado Ekiti. Chi-square statistics were used to test the hypotheses. Results show that majority of the respondents have negative views about building related skills, which are found to be greatly influenced by the family's occupational background and gender differences. In order for the nation to achieve its economic and social goals, intensive campaign strategies are required to disabuse the minds of the populace against these perceptions. It concludes by highlighting some of these strategies.
\end{abstract}

Keywords: Attitude, Building, Entrepreneurship, Parental Influence, Technical Education, Vocational Skills

\section{Introduction}

Entrepreneurship and vocational studies have been known, all over the world, to be a catalyst for job creation and economic prosperity of societies and their inhabitants. According to Emi (2009), vocational education provides practical skills, knowledge and values that enable the learner to be proficient in a particular occupation. It is essentially designed for individuals who want gainful employment in recognised occupations such as semi-skilled workers, technicians or sub-professionals (Ejiwale, 2004). On the other hand, Entrepreneurship education equips young people with skills, competencies, understanding and attributes that make them to be innovative and to identify, create and initiate personal and /or community businesses (Jimoh, 2012; Goel, et al, 2006; Azubuike, 2011). Also, it enables those who engage themselves either in vocational trades or business ventures to manage the human and material resources that are necessary for their business both efficiently and successfully. Therefore, Entrepreneurship and vocational studies complement each other in helping learners become self-employed and self-reliant.

Entrepreneurship and vocational education have been neglected by the Nigerian government for so many years resulting in under-development and poverty. Gasper (2011) and Emi (2009) observed that majority of Nigerian graduates in the past three decades studied mainly in the liberal arts, natural and physical sciences that are not vocational in orientation. Consequently, the graduates were made to wholly depend on public and private sectors for employment, usually as administrators and school teachers (Emi, 2009; Azubuike, 2011).

It is in realisation of this shortcoming that the federal 
government directed all tertiary institutions in the country to include entrepreneurship and vocational education as a compulsory course for all students. This was meant to redirect the youths to technical and entrepreneurial skills for self-employment. Each student is made to undergo training in a particular skill in addition to his chosen course of study. This is expected to produce high quality technical skills needed in the country; skills that are also essential for economic and social development of the country. Such skills include, building related trades that have been found to constitute the main workforce in the construction industry- a sector that has been identified as a key indicator and driver of economic activity and job creation (Kenyl, 2007; Toluhi, 2010; Idoro \& Bamidele, 2010). Recent studies conducted by various scholars, however, revealed a very low enrolment in these skills at both the higher institutions and secondary schools (Awe, et al, 2011; Adewale, et al, 2014). The enrolment percentages in the tertiary institutions range from 8.1 to $16.5 \%$. It was noted that no student registered for Painting \& Decoration, Plumbing \& Pipe fitting, Carpentry and Tiling. The situation at secondary school level does not fare well either. Okocha (2009), in her evaluation of the Trends of Students' Enrolment for Vocational Subjects in Secondary Schools in Abia State, reported that majority of students in these schools displayed apathy towards the building-based skills.

The question of why students show little or no interest in Building-based vocational skills have been taken up by scholars. Most of these however offered explanations that are based on untested assumptions and guesses which cannot be relied upon for valid policy decision-making and theory building. Besides, the context of their studies were different from the current study thus, raising the question of applicability of their findings to the one in question. The purpose of this paper is to provide an empirical-based evidence for the influence of family's background and gender on the attitude of Nigerian Polytechnic students towards building-based vocations. The following hypotheses are hereby presented for testing:

$\mathrm{H}_{1}$ : The family's occupational background of a student will have an impact on his/her attitude towards building related vocations. Therefore, students from technical related family occupational backgrounds will be more positive towards building related vocations.

$\mathrm{H}_{2}$ : The gender of students will have an impact on his/her attitude towards building related vocations. Therefore, male students will be more positive towards building related vocations.

\section{Literature Review and Conceptual/Theoretical Framework}

\subsection{Literature Review}

The negative trend in students' enrolment in building-based vocational skills has generated a wide interest among scholars.
Adewale, et al (2014), for instance, observed that, despite the contribution of construction industry to employment generation and vocational training opportunities, few students of higher institutions enrolled in building-based vocations. They cited the risky and economically unstable nature of building construction activities and the scaring news of incessant building collapse as some of the possible reasons students develop apathy towards the vocations. They also argued that the repeated layoffs and hiring of personnel that characterise the building industry, may discourage the students from taking up such vocations as their lifetime career. In their own explanation, Awe, et al (2011) contend that many students are not willing to choose building-related vocations because they regard such careers as ignoble and meant for the poor.

A number of studies have given a clue on the possible influence of social structure on the formation of such attitudes. For example, Goel, et al (2006) in their comparative study, Attitude of Youths towards Entrepreneur and Entrepreneurship in India and China found that family's background and parental role-modelling was a prominent factor that affected formation of attitudes towards entrepreneurship. In a similar study conducted in Udu Local Government area of Delta State, Nigeria, Azubuike (2011) explored the influence of parent on choice of vocational skills by secondary students and concluded that the parent's position in society influenced the student's interest in studying vocational subjects. However, given the psychological importance of the age of Polytechnic students, who are self-focused and relatively freed of the parent and society, directed routine of school, and thus take decisions on their own (Munsey, 2006); the certainty that this postulation also holds true for choice of vocational skills by students in the Nigerian tertiary institutions is, therefore, in doubt.

Previous studies also indicate that family's background alone may not be sufficient to explain the formation of attitudes towards career choice. Personal factor like gender has been found to be one of the factors that affect students' attitude towards building-based vocations. For example, Bello, et al (2007) in their study conducted among secondary schools in Bauchi found that more male students enrolled in building vocations than their female counterparts. According to the study, none of the female participants registered for Plumbing and Block laying. Similar observation was made by Ajayi (2000) who, in her study of gender participation in housing production and management, noted that few women chose building professions. She attributed this to the widely held view that sees females as the weaker sex and may be incapable of performing building activities which are considered to be energy-requiring tasks. These inferences were however based upon observed patterns or simple repetition of events only, leaving the statistical significance of the results untested. The possibility that these observations occurred by chance cannot be ruled out. Further research that establishes the empirical evidence on the influence of gender on career choice is, therefore, essential. 


\subsection{Conceptual/Theoretical Framework}

The Theory of Planned Behaviour was used for the study. The theory was developed by Ajzen \& Fishbein (1980) as an extension of their theory of reasoned action which was first introduced in 1967 by Fishbein. It proposed that behaviour results from the combination of two factors: (1) Intention to act in a particular way (i.e. motivation) and (2) Ability to act in that way (i.e. perceived behavioural control). The theory explains further that this 'intention to act' is a function of attitudes and subjective norms. According to the theory, attitude is determined by a person's beliefs about the outcomes or attributes of performing a behaviour (Miller, 2005). This implies that individuals act primarily on the basis of their attitudes and values.

The subjective norm is seen by the theory as perceived expectations from relevant individual or group along with intentions to comply with these expectations. The theory argues that a person's intention to act in a particular way depends on whether these important referents approve or disapprove of the performance of the behaviour in question, which in turn, is a function of the person's motivation to comply with those referents (Ajzen \& Fishbein, 1980; Montano \& Kasprzyk, 2002). The concept of subjective norm accounts for the role of socialisation in shaping individual's behaviour. Socialization includes messages about what is good and positive, what lends status, what is valued by others etc. As postulated by psychologists, an individual's socialization takes place at home, at the place of education, and in other spheres of interaction (Goel, et al, 2006). Among these socialising agents, family background and parental role-modeling has been found to be the most prominent factor that influences the formation of attitude towards entrepreneurship (Matthews \& Moser, 1995; Scott \& Twomey, 1988). Early communication received and imbibed by an individual from the family would impact career choices by inducing individuals to choose a career in which they are viewed positively by society.

In order to account for factors outside a person's volitional control that may affect his/her intentions and behaviour, Ajzen (1991) later proposed the theory of planned behaviour by adding perceived behavioural control to the theory of reasoned action. This theory explained that perceived behavioural control is determined by control beliefs concerning the presence or absence of facilitators and barriers to behavioural performance, which are, in turn, weighted by the perceived power or input of each factor to facilitate or inhibit behaviour. Thus, a person who holds strong control beliefs about factors that facilitate behaviour will have high perceived control, which translates into an increased intention to perform such behaviour (Ajzen, 1991; Montano \& Kasprzyk, 2002).

In the current study, the theory of planned behavior was used to explain the students' attitudes, their intentions and behaviours relating to their enrolment in building-related vocational skills. This was based on the assumption that if family and the society at large view building related vocational skills as valuable and positive, students would be encouraged to embrace building related subjects as a career of choice during their studies in higher institutions.

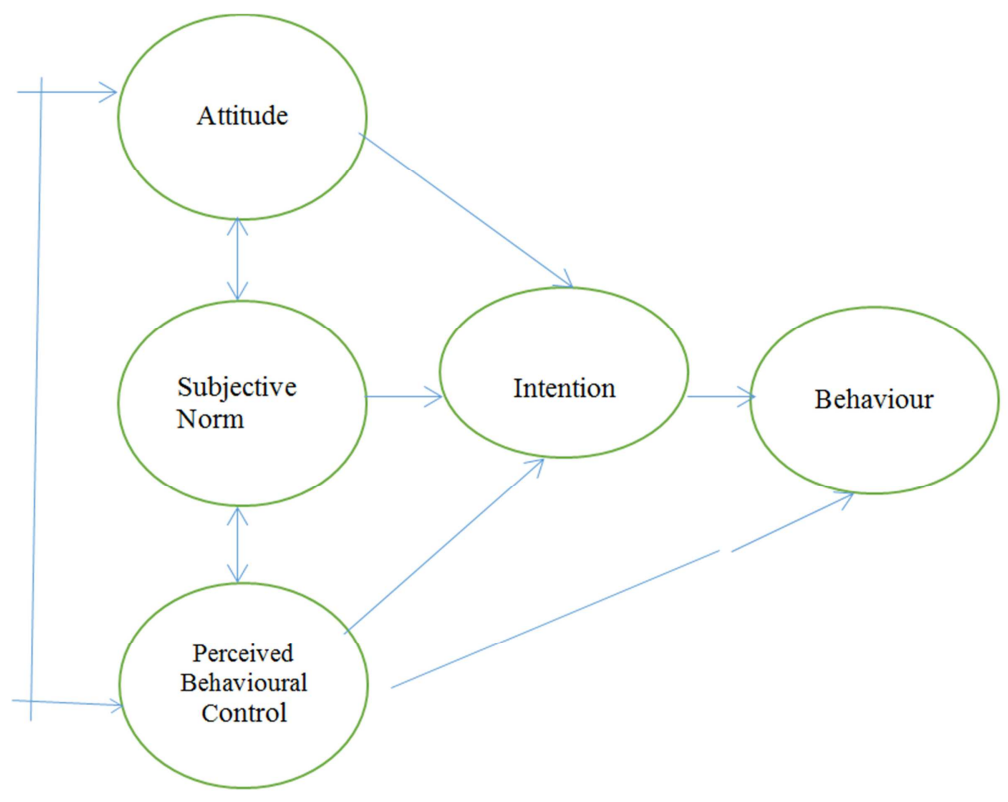

Figure 1. Ajzen theory.

\section{Methodology, Results and Conclusion}

\subsection{Methodology}

The Study Setting

The location of the study the Federal Polytechnic, Ado
Ekiti formerly known as College of Technology. It lies approximately on $3^{\circ} 4^{\prime}$ east of Greenwich meridian and latitude $8^{\circ} 4^{\prime}$ north of the equator. The Campus is about 2.0 and 2.6 kilometres from Ekiti State Secretariat and the King's Palace respectively.

The Polytechnic has a student population of 5,150 in 25 
academic departments. They include, Accountancy department; Banking and Finance; Business Administration and Management department; Marketing; Office Management and Technology; Agricultural and Bioenvironmental Engineering; Agricultural Technology; Civil Engineering; Electrical/Electronic Engineering; Mechanical Engineering; Mineral Resources Engineering; Architectural Technology; Building Technology department; Estate Management; Quantity Surveying; Surveying and Geoinformatics; Urban and Regional Planning; Computer Science; Food Technology; Glass and Ceramic Technology; Mathematics and Statistics; and Science Technology.

The Polytechnic started offering entrepreneurship programme in 2010/2011 session in line with the National Board for Technical Education's (NBTE) guidelines. The courses which are run and monitored by the Centre for Entrepreneurship Development and Vocation Studies are taken by the students at all levels of their programme. The Centre also trains students in vocational skills such as Snailry; Repair and Reproduction of simple electrical gadgets; Tie and Dye; Welding and Fabrication; Turkey Brooding and Rearing; Soap making; Vegetable and Plantain Production; and Bee Keeping. The training in one of these skills is taken by the students in the second semester of each session.

Data Collection

The data for this study were collected by the use of structured questionnaire consisting of two parts. The first part was designed to provide answers to the questions relating to the factors affecting the attitude of students towards building related skills. The questionnaire consisted of close-ended questions that sought for demographic data of the respondents. Subjects were, however, asked to give free response to the question relating to the type of occupation of the breadwinner of the family. These were later categorised into four occupations: (i) Technical (ii) Business (iii) Agriculture (iv) Service workers.

The second part contains the Attitude of Students towards Building-related Vocational Skills (ASTBVS) scale developed by the authors. In developing the scale, 10 critical statements derived from the literature were used. These statements were either negatively or positively framed. The statements reflected the students' expressed emotional and personal issues, beliefs, behaviours and experiences about building-related vocational skills. The ten used statements were rated on a 5-point scale ranging from strongly agree to strongly disagree.

The instrument was pretested on Year Two Accounting students of the same institution who were not part of the study. Most of the items in the questionnaires were found to be well understood and easy to fill. The few ambiguities noticed were rectified and the confusing statements were recast with the guidance of six experts who also ascertained the face and content validity of the instrument. The questionnaires which were later administered on 358 Year Two students randomly drawn from three departments from each of the four faculties (Business studies, engineering, environmental studies and school of computer studies and sciences). The questionnaires were distributed to the available students at the end of their lectures on entrepreneurship education who willingly completed same on the spot within twenty minutes. In analysing the data for the attitude of the students towards the programme, Likert scoring method was used. For positive statements, the answer categories were rated thus: 5(strongly agree), 4(agree), 3(Undecided), 2 (disagree), and 1(strongly disagree). The pattern was reversed for negative statements. Total scores for each subject were obtained by adding their scores on the ten items. Scores that fell within the interval of 1-20 were considered as expressing unfavourable attitudes. Scores within the interval of 21-39 were considered neutral or ambivalent while scores within 40 - 50 were considered as favourable. The results obtained were expressed in percentages. The responses to each statement were further analysed using the mean item score computed as follows:

Mean Item Score (MIS) $=\frac{5 n_{5}+4 n_{4}+3 n_{3}+2 n_{2}+1 n_{1}}{N}$

where $\mathrm{n}_{1}=$ number of respondents that strongly disagree (for positive statement) or strongly agree (for negative statement)

$\mathrm{n}_{2}=$ number of respondents that disagree (for positive statement) or agree (for negative statement)

$\mathrm{n}_{3}=$ number of respondents that are undecided

$\mathrm{n}_{4}=$ number of respondents that agree (for positive statement) or disagree (for negative statement)

$\mathrm{n}_{5}=$ number of respondents that strongly agree (for positive statement) or strongly disagree (for negative statement)

$\mathrm{N}=$ total number of respondents.

Statements with mean item score of 4.0 and above were considered positive attitude while the ones that have their mean item score falling between 2.5 and 3.9 are said to be neutral. Those statements whose mean item scores fall below 2.4 are considered negative attitude. In order to test the two hypotheses, the attitude scores were further subjected to Chisquare analysis, using 95\% confidence level.

\subsection{Results and Discussion}

Table 1 summarises the distribution of the respondents' attitude. A large number of them (86\%) have negative attitude towards building-based vocations. Just $6 \%$ of the respondents can be said to have favourable attitude towards the vocations.

Table 1. Respondents' attitude towards building-based vocational Skills.

\begin{tabular}{lll}
\hline Attitude & Frequency & Percentage (\%) \\
\hline Favourable & 22 & 6 \\
Neutral & 30 & 8 \\
Unfavourable & 306 & 86 \\
Total & 358 & 100 \\
\hline
\end{tabular}

Source: Authors' Fieldwork (2015) 
The item-by-item analysis of the views of the respondents in Table 2 further establishes this finding. Six out of ten items responded to by the participants' elicited unfavourable responses towards the building-based vocational skills. For example, more than three-quarter of the respondents agreed to the item, "Public esteem accorded this category of workers is low". Similar trend was also observed with people's view about the nature of building craftsmanship. Seventy-five per cent agreed that building workers are exposed to high level of risks and that the fortune of building construction industry in general is tied to economy of the nation which is, most of the time, unstable. Sixty-five per cent also held that building trades are more laborious than other trades.

Table 2. Item-by-item analysis of respondents' attitude towards building-based vocational skills.

\begin{tabular}{|c|c|c|c|c|c|c|c|c|}
\hline \multirow{2}{*}{$\mathbf{S} / \mathbf{N}$} & \multirow{2}{*}{ Respondents' Attitude } & \multicolumn{6}{|c|}{ RESPONSES $(\mathrm{N}=358)$} & \multirow{2}{*}{ Remark } \\
\hline & & SA & $\mathbf{A}$ & $\mathbf{U}$ & D & SD & MIS & \\
\hline 1. & Public esteem accorded building related skills is low. & $134(37)$ & 141(39) & $47(13)$ & $30(8)$ & $6(2)$ & 2.0 & $\begin{array}{l}\text { Negative } \\
\text { Attitude }\end{array}$ \\
\hline 2. & $\begin{array}{l}\text { Most graduates in this field find it very difficult to secure } \\
\text { employment. }\end{array}$ & $132(37)$ & $92(26)$ & $57(16)$ & $72(20)$ & $5(1)$ & 2.3 & $\begin{array}{l}\text { Negative } \\
\text { Attitude }\end{array}$ \\
\hline 3. & Building workers are exposed to high level of risks. & 193(54) & $96(27)$ & $37(10)$ & $20(6)$ & $12(3)$ & 1.8 & $\begin{array}{l}\text { Negative } \\
\text { Attitude }\end{array}$ \\
\hline 4. & $\begin{array}{l}\text { Rewards from building trade are less in comparison to the hard } \\
\text { work required. }\end{array}$ & $83(23)$ & 133(37) & $66(18)$ & $68(19)$ & $16(5)$ & 2.3 & $\begin{array}{l}\text { Negative } \\
\text { Attitude }\end{array}$ \\
\hline 5. & Building trades are more laborious than any other trade. & $130(36)$ & $112(31)$ & $65(18)$ & $49(14)$ & $2(1)$ & 2.2 & $\begin{array}{l}\text { Negative } \\
\text { Attitude }\end{array}$ \\
\hline 6. & $\begin{array}{l}\text { The fortunes of building construction industry are tied to } \\
\text { economy which, most of the time, is unstable. }\end{array}$ & $94(26)$ & $147(41)$ & $76(21)$ & $32(9)$ & $9(3)$ & 2.2 & $\begin{array}{l}\text { Negative } \\
\text { Attitude }\end{array}$ \\
\hline 7. & $\begin{array}{l}\text { My friends and I need to be engaged in building trade to fix } \\
\text { the country. }\end{array}$ & $74(21)$ & $72(20)$ & $21(6)$ & $113(32)$ & $78(22)$ & 2.9 & Neutral \\
\hline 8. & Building workers live good family life. & $82(23)$ & $89(25)$ & $8(2)$ & $101(28)$ & $75(21)$ & 2.8 & Neutral \\
\hline 9. & $\begin{array}{l}\text { When looking for a life partner for my sibling/cousin (myself) } \\
\text { we would prefer a person who has building related skills. }\end{array}$ & $68(19)$ & $29(8)$ & $97(27)$ & $102(29)$ & $62(17)$ & 2.8 & Neutral \\
\hline 10. & Building craftsmen are richer than their counterparts. & $54(15)$ & $62(17)$ & $96(27)$ & $71(20)$ & $75(21)$ & 2.8 & Neutral \\
\hline
\end{tabular}

Notes: $1 . \mathrm{SA}=$ Strongly Agree, $\mathrm{A}=$ Agree, $\mathrm{U}=$ Undecided, $\mathrm{D}=$ Disagree, $\mathrm{SD}=$ Strongly Disagree, MIS= Mean Item Score, 2. Figures in parentheses are row percentages.

Source: Authors' Analysis (2015)

The table also reveals that the remaining four items have a mean score that is within 2.5-2.9, indicating ambivalent attitude. While $41 \%$ of the respondents agreed that they needed to engage in building trade to reinstate the economic situation of the country, $53 \%$ disagreed with the statement. The story is the same with the perception of people about the family life of building workers. About $45 \%$ of the respondents believed that building workers live a good family life, while $48 \%$ disagreed. The mean score also reveals that majority of the respondents were undecided whether they could choose a building craftsman as life partner either for themselves or for their relatives. All these negative views about building craftsmanship support the claims by the previous studies (Adewale, et al, 2014; Awe, et al, 2011) which linked the students' apathy to these beliefs.

Table 3. Chi-square statistics testing dependency of attitude of polytechnic students towards building-based vocational skills on selected demographic variables.

\begin{tabular}{|c|c|c|c|c|c|c|c|c|}
\hline \multirow{2}{*}{$\begin{array}{l}\text { Demographic } \\
\text { Variables }\end{array}$} & \multirow{2}{*}{ Categories } & \multicolumn{3}{|l|}{ Attitudes } & \multirow{2}{*}{$\chi^{2}$ (cal) } & \multirow{2}{*}{ Df } & \multirow{2}{*}{$\chi^{2}($ tab) } & \multirow{2}{*}{ Remarks } \\
\hline & & Favourable & Neutral & Unfavourable & & & & \\
\hline \multirow{4}{*}{$\begin{array}{l}\text { Family's } \\
\text { occupational } \\
\text { background }\end{array}$} & Technical & $8(18)$ & $3(7)$ & $33(75)$ & \multirow[t]{4}{*}{30.784} & \multirow[t]{4}{*}{6} & \multirow[t]{4}{*}{12.592} & Significant \\
\hline & Agriculture & $7(15)$ & $8(17)$ & $31(68)$ & & & & At $\mathrm{P}<0.05$ \\
\hline & Business & $3(4)$ & $6(8)$ & $63(88)$ & & & & \\
\hline & Services & $4(2)$ & $13(7)$ & $179(91)$ & & & & \\
\hline \multirow[t]{2}{*}{ Gender } & Male & $19(10)$ & $22(12)$ & $149(78)$ & \multirow[t]{2}{*}{17.097} & \multirow[t]{2}{*}{2} & \multirow[t]{2}{*}{5.991} & Significant \\
\hline & Female & $3(2)$ & $8(5)$ & $157(93)$ & & & & At $\mathrm{P}<0.05$ \\
\hline
\end{tabular}

Notes: Figures in parentheses are row percentages.

Source: Authors' Analysis (2015)

According to Chi-square analysis in Table 3, these attitudes are influenced by parental occupation. As can be seen in the table, students whose parents engage in technical job displayed more positive attitude than those ones whose families are businessmen or service workers. It is possible that people from technical occupational background have a better understanding of building-based vocations right from their training days and do not romanticise it. They may be aware of the risks in these vocations and the safety measures put in place to avert the consequences. Service and business background people on the other hand might receive second hand knowledge about the vocations and therefore their perception is likely to be based on the success stories published about building professionals or craftsmen which are likely to be greatly distorted. 
The Chi-square analysis also shows that the attitude of polytechnic students towards building-related skills depend on gender. More male students than female students displayed favourable attitude towards building-based vocational skills. Just three out of 168 female respondents exhibit positive attitude. The reason for this could be traced to the cultural perception about the built environment professions which sees these professions as masculine professions (Ajayi, 2000). Hammond (2009) argues that society, especially the patriarchal society has made stardom something elusive for women in the built environment to reinforce this belief. Some studies even reported that the few ones in the professions often complain of hostile organisational climate characterised by non-supportive supervisors or co-workers and general incivility. This apparent lack of role models and discrimination may discourage female students from taking up building-based vocation as a skill or career. One grave consequence of this is that female students would continue to stay away from the vocations. Consequently, dearth of building craftsmen or technicians would continue to affect the economic growth of the country, as this category of students are becoming more in number than their male counterpart in the overall enrolment.

\subsection{Conclusion and Recommendations}

This paper has thus far examined the perception of polytechnic students about building-based vocations. It demonstrated that overwhelming majority of polytechnic students have negative attitude towards building-based vocational skills. Most of them perceived building craftsmanship to be ignoble, unrewarding and undesirable vocation for contributing to the country's development. Obviously, these views could not make them to embrace building-based vocations. For the nation to achieve its socioeconomic goals, therefore, intensive campaign strategies are required to enlighten the populace against these perceptions.

As revealed by the paper, these attitudes are influenced by the students' family occupational background. It could thus be inferred that early exposure to vocational skills would help students to develop right attitude to a particular vocation. Therefore, in setting up programmes and designing intervention to encourage people to take up building-based vocational skills as a career, it would help to provide inputs at secondary school level rather than after the person has completed his/ her professional or university education or when the person has failed to get a job.

The results suggest that students from families with technical occupational background have more positive attitude than their colleagues from families with business or service as the major family occupation. This, according to the paper, could be linked to a better understanding of building vocation as a result of first-hand knowledge the former could have, compared to the latter who might have received distorted information from the public. Adequate programmes that educate all categories of students about the nature of built environment professions in higher institutions are therefore, very essential.
A significant relationship was also found between students' attitude and gender. Male students show more positive attitude than their female counterpart. According to the study, this could be due to apparent lack of role models and incivility suffered by the few females in this field. The best strategy to counter this is to continue to raise the profile or identity of women in the built environment. The chief executive officers and top management should foster a culture of inclusiveness, helping to create clear paths for advancement and enforcing a zero tolerance policy for incivility and undermining. All these will encourage female student to develop interest in the vocations, which will ultimately lead to the increase in enrolment in building-based vocational skills at the vocational centres of Nigeria tertiary institutions.

\section{References}

[1] Adewale, PO, Siyanbola, AB \& Siyanbola, SO (2014) 'Building-Craftsmanship Skill Development and Vision 20:2020: Imperatives and Daunting Challenges', International Journal of Vocational and Technical Education, Volume 6, No 4, pp. 36-43.

[2] Ajayi, MO (2000) 'Appraising Gender Participation in Housing Production and Management in: Akinbamijo, OB, Fawehinmi, AS, Olotuah, AO \& Ogunsemi, DR (eds) Effective Housing in the $21^{\text {st }}$ Century Nigeria, Akure: The Environmental Forum, pp. 215-219.

[3] Ajzen, I. (1991) 'The Theory of Planned Behaviour', Organisational Behaviour and Human Decision Processes, 50, pp. 179-211.

[4] Ajzen, I. and Fishbein, M. (1980) Understanding Attitudes and Predicting Social Behaviour, Englewood Cliffs: PrenticeHall.

[5] Awe, E. M, Griffith, A. \& Stephenson, P. (2011) 'Militating Against Youth Interest in Construction Crafts Careers: Panacea for Effective PPP Implementation in Nigeria' in: Professor Akintoye, A, Liyanage, C. \&Renukappa, S. Public Private Partnerships.

[6] Azubuike, OC (2011) 'Influential Factors Affecting the Attitude of Students towards Vocational/Technical Educational Subjects in SecondarySchools in Southeastern Nigeria', Journal of Educational and Social Research, Volume 1, No 2, pp. 49-56.

[7] Bello, MI, Danjuma, IM \& Adamu, AY. (2007) 'A. Survey of Vocational Training Needs of 15-25 Years OldOut-of-School Youths in Bauchi Metropolis', Journal of Career and Technical Education, Volume 23, Number 1.

[8] Ejiwale, PO. (2004) 'The Role of Technical Education in National Development', The Pacesetter, Volume 11, No 2, pp. $147-156$.

[9] Emi, RA. (2009) 'Vocational and Entrepreneurship Studies: TASUED Experience, 2005-2009 in: Oyesiku, K, Ogunsaju, S. \& Olusanya, JA. (eds) Tai Solarin University of Education Growth and Development, Ijagun: Tai Solarin University of Education Press, pp. 198-215. 
[10] Gasper, OA. (2011) 'Entrepreneurial Polytechnic: A. Catalyst for Nigeria's Attainment of Vision 20:2020', Convocation Lecture delivered at the Federal Polytechnic, Ado Ekiti on $12^{\text {th }}$ October.

[11] Goel, A, Vohraet, N, Zhang, L \& Arora, B. (2006) 'Attitudes of the Youth towards. Entrepreneurs and Entrepreneurship: a Cross-cultural Comparison of India and China', Journal of Asia Entrepreneurship and Sustainability, Volume III, Issue I, pp. 1-34.

[12] Halle, JL, Householder, BJ. and Greene, KL. (2003) 'The Theory of Reasoned Action In J. P. Dillard and M. Pfau (eds.)' The Persuasion Handbook: Developments in Theory and Practice, Thousand Oaks: Sage, pp. 259-286.

[13] Hammond, C. (2009) 'Past the Parapets of Patriarchy? The Star System and the Built Environment, Atlantis, 34 (1), pp 111. Also Available at: www.msvu.ca/atlantis. Retrieved on 1303-2016.

[14] Idoro, GI. \& Bamidele, EO. (2010) 'Health and Safety Performance of Selected. Construction Firms and the Achievement of the Millennium Development Goals' in Fadare, SO. \& Adesanya, DA. Sustainable Environment, IleIfe: Obafemi Awolowo University Press, pp 165-178.

[15] Jimoh, AA. (2012) 'Importance of Entrepreneurship Education', FEDPOLAD News, pp. 6.

[16] Kenyl, C. (2007) 'Construction, Corruption and Developing Countries', World Bank Policy Research Working Paper 421.
[17] Matthews, CH, \& Moser, SB. (1995) 'Family Background and Gender: Implications for Interest in Small Firm Ownership', Entrepreneurship and Regional Development, 7, 365-377.

[18] Miller, K. (2005) Communications Theories Perspectives, Processes and Context, New York: McGraw-Hill.

[19] Montano, DE. \& Kasprzyk, D. (2002) 'The Theory of Reasoned Action and the Theory of Planned Behaviour', In K. Glanz, B. K. Rimer, \& F. M. Lewis (Eds.), Health Behaviour and Health Education: Theory, Research and Practice, San Francisco: Jossey Bass,pp. 67-98.

[20] Munsey, C. (2006) 'Emerging Adults: The in-between Age', Monitor on Psychology, Vol 37, No 6, pp. 8.

[21] Okocha, M. (2009) 'Parental Attitudes towards Vocational Education: Implications for Counselling', Edo Journal of Counselling, Volume 2, No 1, pp. 81-89.

[22] Scott, MG, \& Twomey, DF. (1988) 'The Long Term Supply of Entrepreneurs: Students' Career Aspirations in Relation to Entrepreneurship' Journal of Small Business Management, 26, $5-13$.

[23] Toluhi, JO. (2008) Failures, Safety Measures and Risks in Construction. Paper presented at the Nigerian Institute of Architects' (N. I. A.) Professional Practice Examination Held at N. I. A. National Secretariat, Abuja on 9 September. 